\title{
Resurrecting Pufendorf and capturing the Westphalian moment
}

\author{
DAVID BOUCHER ${ }^{1}$
}

\begin{abstract}
In this article I intend to give more attention to Pufendorf's ideas than has been the custom among international relations theorists. The main focus will be upon Pufendorf's distillation and conceptualization of the implications of Westphalia in terms of sovereignty and the integrity of states. Furthermore, his extension of the Aristotelian classification of types of state, and his attempts to go beyond Bodin's and Hobbes's theories of sovereignty, provide the vocabulary and concepts in terms of which the different international actors of the late seventeenth century could be understood. In this respect the focus is altogether different from Linklater. My emphasis upon the historical and emblematic character of the Peace of Westphalia, the personification of the state and its animation by sovereignty, which serves to facilitate Pufendorf's exploration of the idea of a system of states, and my suggestion that his ideas are not wholly redundant and may be used to explore some facets of a modern states system, serve considerably to extend Forsyth's brief analysis.
\end{abstract}

Samuel von Pufendorf was one of the most famous moral and political philosophers of his day providing an authoritative reference point in terms of which theorists addressed the major contemporary controversies. ${ }^{2}$ His contribution as one of the leading theorists of international law was acknowledged by the Carnegie Endowment for International Peace in the early part of this century with the translation and publication of his major works on natural law. With the demise of liberal internationalism during the inter-war period, the prospect of Pufendorf becoming a central figure in the study of international relations considerably receded. He has, in fact, been almost completely ignored by contemporary international relations theorists. ${ }^{3} \mathrm{He}$

1 I am deeply indebted to the Nuffield Foundation and the British Academy for awarding me grants to pursue the issue of the expansion of the moral community in international relations. This article is part of that larger project.

2 For Pufendorf's brief account of the importance of his predecessors, see The Law of Nature and Nations, preface, pp. v-vii. For a discussion of Pufendorf's much longer account in Specimen controversiarum circa jus naturale ipsi nuper motarum (1678) see Richard Tuck "The "modern" theory of natural law' in Anthony Pagden (ed.), The Languages of Political Theory in Early-Modern Europe (Cambridge: Cambridge University Press, 1987).

3 Samuel Pufendorf, On the Duty of Man and Citizen According to the Natural Law (1672), translated by W. A. Oldfather (Oxford: Clarendon Press, 1927); The Elements of Universal Jurisprudence (1658), translation of the 1672 edition by W. A. Oldfather (Oxford: Clarendon Press, 1931); On the Law of Nature and Nations, Eight Books (1672), translation of the 1688 edition by C. H. Oldfather and W. A. Oldfather (Oxford: Clarendon Press, 1934). A recent translation of On the Duty of Man and Citizen by James Tully has been published by Cambridge University Press, 1991. On the Natural State of Men has recently been translated into English for the first time by Michael Seidler and is published by Edwin Mellon Press, Lampeter (1990). Both the recent translations are reviewed by F. Palladini, 'Translating Pufendorf', History of Political Thought, XVI (1995). The Political Writings of Samuel Pufendorf has been edited by Craig L. Carr, translated by Michael J. Seidler and published by Oxford University Press, 1994. 
has not even merited inclusion in the immensely wide-ranging anthologies that have recently been published. ${ }^{4}$

There are some texts on international relations that acknowledge Pufendorf's importance by merely making passing reference to his conclusions without giving his reasons for reaching them. Martin Wight acknowledges that it was Pufendorf who coined the term 'systems of states' which serves as the title for his own book. Wight simply gives Pufendorf's definition: 'several states that are connected as to seem to constitute one body but whose members retain sovereignty'. Wight wrongly suggests that it was later writers who distinguished this concept into unions between states and confederations. ${ }^{5}$ Elsewhere Pufendorf is cited in relation to uscapation, the right by which continuous use confers property rights upon a possessor against a known former owner, and in the context of distinguishing between a truce and a peace. ${ }^{6}$ Terry Nardin cryptically asserts, in passing asides, Pufendorf's importance in relation to the idea of an international society; the formal equality of states; the idea of a states system; and, the denial that international law is law properly understood. ${ }^{7}$ Nicholas Onuf similarly makes passing reference to the importance of Pufendorf. He suggests, for example, that Pufendorf makes the simple but incredibly modern point that states must be sovereign in order to be states. ${ }^{8}$ Onuf also claims that Pufendorf's On the Law of Nature and Nations is to be counted among those treatises on the law of nature that are 'nothing but catalogues of duties proclaimed on behalf of nature'. ${ }^{9}$ This is a considerable distortion of Pufendorf's enterprise because it is not the duties themselves which are interesting, but the arguments by which Pufendorf arrives at them. The fact that he contends that American Indians, for example, have rights and duties in respect of their lands even though there are no signs of occupancy, such as demarcation and cultivation, is a mere assertion without the argument to sustain it. In distinguishing between private property and 'eminent domain' he not only restricts the grounds on which colonial expansionism can be justified, but also provides the justificatory argument for the integrity of territorial sovereignty. Eminent domain, he argues, is the right of communities, including states, over the property of its members or citizens. The implication of this is that irrespective of whether one takes the American Indians to be living in a state of nature, as Grotius and Locke do, they are still to be understood as exercising the property right of 'occupancy as a whole' and determining its use and distribution by title of eminent domain. ${ }^{10}$

Of the secondary sources on classic international theory Andrew Linklater's Men and Citizens in the Theory of International Relations, and Murray Forsyth's Unions

${ }^{4}$ See, for example, Howard P. Kainz (ed.). Philosophical Perspectives on Peace (London, Macmillan, 1987); John A. Vasquez (ed.), Classics of International Relations (Englewood Cliffs, NJ: Prentice Hall, 1990); Evan Luard, Basic Texts in International Relations (London: Macmillan, 1992); and Howard Williams, Moorhead Wright and Tony Evans (eds.), A Reader in International Relations and Political Theory (Buckingham: Open University Press, 1993).

${ }^{5}$ Martin Wight, Systems of States (Leicester: Leicester University Press, 1977), p. 21.

${ }^{6}$ Wight, Systems of States, pp. 159 and 165.

7 Terry Nardin, Law, Morality, and the Relations of States (Princeton, NJ: Princeton University Press, 1983), pp. 41n, 54, 58, 58n, 70, and 70n. Nardin also points out that Pufendorf was one of Kant's 'sorry comforters', p. 74.

${ }^{8}$ Nicholas Greenwood Onuf, The Republican Legacy in International Thought (Cambridge, Cambridge University Press, 1998), p. 123.

${ }_{9}$ Onuf, The Republican Legacy, p. 53.

${ }^{10}$ Pufendorf, The Law of Nature and Nations, IV, vi, p. 4. 
of States: The Theory and Practice of Confederation are notable exceptions in giving Pufendorf a prominent place. ${ }^{11}$ On the assumption that our obligations to fellow human beings ought to trump those of our obligations as citizens - although there is no necessary reason for them to be incompatible-Linklater condemns Pufendorf for failing to remain faithful to his principles of natural law in giving priority to the rights of citizens. Pufendorf is not so much recommending a desired and wished-for state of affairs, the state of affairs that Linklater desires, namely, a worldwide moral community that supersedes the modern states system, but instead he attempts to theorize the international arena as it emerges from the Peace of Westphalia. It is anachronistic to think that Pufendorf could and should have superseded in his theoretical explorations something that no theorist had yet more than partially understood. His achievement was, in fact, to develop our conceptual vocabulary in a way that could accommodate and capture what was happening at the international level in his day. In other words, Pufendorf's main concern was trying to theorize what was rather than what ought to be, what confronted him, rather than what it might yet become. This, I think, is something that Murray Forsyth recognizes. For him Pufendorf is important because he recognized that political formations such as the Swiss Confederation, The United Provinces and the German Empire did not conform to the received conception of a sovereign state, and yet appeared to go beyond conventional leagues and alliances which characterized much of the international relations of his day.

Historians of philosophy and political thought, in contrast with international relations theorists in general, have recognized Pufendorf's importance as an adept synthesizer of the central ideas of Grotius and Hobbes. Pufendorf has been identified as central to the natural jurisprudence of the Scottish enlightenment ${ }^{12}$ and to the development of the doctrines of natural law and natural rights. In particular, and of considerable importance for understanding the Westphalian system of international relations, he made original contributions to the development of social contract theory, and the theory of property. ${ }^{13}$

In this article I intend to give much more serious attention to Pufendorf's ideas than has become customary from international relations theorists. The main focus of this article will be upon Pufendorf's distillation and conceptualization of the impli-

11 Andrew Linklater, Men and Citizens in the Theory of International Relations, 2nd edn. (London: Macmillan, 1990), and Murray Forsyth, Unions of States: The Theory and Practice of Confederation (Leicester: Leicester University Press, 1981). In addition, Charles Beitz devotes three pages to Pufendorf in his Political Theory and International Relations (Princeton, NJ: Princeton University Press, 1979).

12 See, for example, Knud Haakonssen, 'Hugo Grotius and the History of Political Thought', Political Theory, 13 (1985); Knud Haakonssen, 'Natural Law and Moral Realism: The Scottish Synthesis', Studies in the Philosophy of the Scottish Enlightenment (Oxford: Clarendon Press, 1990); T. Mautner, 'Pufendorf and 18th century Scottish Philosophy', in K. A. Modéer (ed.), Samuel von Pufendorf 1632-1982 (Lund: Bloms Boktryckeri, 1986).

13 See, for example, Michael Lessnoff (ed.), Social Contract Theory (Oxford: Blackwell, 1990); Stephen Buckle, Natural Law and the Theory of Property: Grotius to Hume (Oxford: Clarendon Press, 1991); Richard Tuck, Natural Rights Theories: Their Origin and Development (Cambridge: Cambridge University Press, 1979), and Robert Wokler, 'Rousseau's Pufendorf: Natural Law and the Foundations of Commercial Society', History of Political Thought, XV (1994). 
cations of Westpahalia in terms of sovereignty and the integrity of states. ${ }^{14}$ Furthermore, his extension of the Aristotelian classification of types of state, and his attempts to go beyond Bodin's and Hobbes's theories of sovereignty, provide the vocabulary and concepts in terms of which the different international actors of the late seventeenth century could be understood. In this respect the focus is altogether different from Linklater. My emphasis upon the historical and emblematic character of the Peace of Westphalia, the personification of the state and its animation by sovereignty, which serves to facilitate Pufendorf's exploration of the idea of a system of states, and my suggestion that his ideas are not wholly redundant and may be used to explore some facets of a modern states system, serve considerably to extend Forsyth's brief analysis.

\section{The historical and emblematic}

In the terms of reference of international political theory, if the Westphalian model signifies anything it does so in no greater degree than in legitimating the priority of community rights, such as those of the state, over those of the individual. The universal rights and duties of the individual under natural law become more precisely conceived as qualified by and mediated through the state as itself a personality possessing rights and duties of its own, and to which obligations are owed. The formal recognition of the notional autonomy and equality of numerous political entities was a further landmark in the process of state formation and the conceptualization of the state as an abstract entity independent of the private person of the monarch or ruler, and the elevation of the subject to the status of citizen, which was to find its quintessential expression in Rousseau's Social Contract. The issue of what duties may be owed to one's fellow citizens, and to the state, and which may be owed to humanity as a whole, while certainly preceding Westphalia, came into sharper focus in the post-Westphalian world.

Here we need to be mindful of the distinction to be made between the language and terms of the treaties themselves and what politically they came to signify. The common view is that Westphalia represents the occasion when states agree to accept constraints on their behaviour out of enlightened rational self-interest, the significance of which is the belief that for the first time sovereignty becomes formally recognized.

The contemporary international relations system so revolves around the idea of sovereignty that a whole series of related settled norms have become common currency among nations, such as the associated ideas of territorial integrity and the principle of non-intervention. Despite the fact that states systematically violate these

${ }^{14}$ In this respect this article may be viewed as an extension of my recent discussion of Pufendorf in which these important aspects of his theory were underplayed. See David Boucher, Political Theories of International Relations from Thucydides to the Present (Oxford: Oxford University Press, 1998), pp. 223-54. An earlier version of this article was given at the 39th Annual Convention of the International Studies Association in Minneapolis, 17-21 March, 1998. A much revised version was presented at a conference organized by Joao Marques de Alemeida, 'International Constitutionalism and the Peace of Westphalia', Arrábida, Portugal, August, 1998. 
norms, to the extent that Stephen Krasner calls it 'organised hypocrisy', ${ }^{15}$ they nevertheless act as constraints. The test of the existence of such norms as moral constraints is that when states are in breach of them they feel compelled to give a justification, or that when they violate them states do so clandestinely. ${ }^{16}$ Such a strong commitment to the norm of sovereignty and the autonomy of the state has understandably led modern writers on international relations, so thoroughly immersed in the practical relevance of their discipline, to engage in what Herbert Butterfield has called Whig history, the tendency to look at the past through the wrong end of the telescope. In international relations theory the Peace of Westphalia has become emblematic of the rise and formal recognition of sovereignty and the emergence of a society of European states. David Held, for example, contends that the Peace of Westphalia 'entrenched, for the first time, the principle of territorial sovereignty in inter-state affairs'. ${ }^{17}$ Alexander B. Murphy claims that the treaties 'did embody an early formalisation of the idea that sovereignty was not simply a characteristic of individual states, but was also a principle that should govern relations between states'. ${ }^{18}$ In addition, Michael Sheenan contends that it 'formally recognized the concept of state sovereignty'. ${ }^{19}$ At the same time sovereignty was not seen as incompatible with compliance with international law, nor with a general recognition of a collective common good. In Hedley Bull's view, Westphalia signifies not the emergence of an international state system, but instead the emergence of an international society comprised of states. ${ }^{20}$

In this respect the past is didactic, having a practical purpose as a shorthand justification of the modern states-system, or as a convenient caricature of a defining moment in the past. Such events, invoked for their practical purpose in contemporary politics, are, to quote Michael Oakeshott: 'abstracted from record in a reading which divests them of their contingent circumstances and their authentic utterance; symbolic and stereotypic personae, actions, exploits and situations'. ${ }^{21}$ Such events or persons are on permanent loan to the present as symbols emblematic of all the vices and virtues of humanity.

The historical character of the Peace of Westphalia is, of course, quite different and extremely more complex than its emblematic character. It reflected the interests of its architects, France, Sweden and Holland, in attempting to diminish the universalist authority of the Papacy and the Holy Roman and Spanish empires of the Hapsburgs, who now became formally equal, at least juridically, with established and emergent states. The participants were not conscious of establishing a new system or state-centred international society, indeed they were of the view that the

15 Stephen Krasner, 'Sovereignty: Organised Hypocrisy'. A paper presented at Arrábida, Portugal, 10 August 1998.

16 See Mervyn Frost, Ethics in International Relations: A Constitutive Theory (Cambridge: Cambridge University Press, 1996), pp. 105-5.

17 David Held, Democracy and the Global Order: From the Modern State to Cosmopolitan Governance (Cambridge: Polity Press, 1995), p. 77.

18 Alexander B. Murphy, 'The sovereign state system as political-territorial ideal: historical and contemporary considerations' in Thomas J. Biersteker and Cynthia Weber (eds.), State Sovereignty as Social Construct (Cambridge: Cambridge University Press, 1996), p. 92.

19 Michael Sheehan, The Balance of Power: History and Theory (London: Routledge, 1996), p. 38.

20 Hedley Bull, 'The Importance of Grotius in the Study of International Relations' in Hedley Bull, Benedict Kingsbury and Adam Roberts (eds.), Hugo Grotius and International Relations (Oxford: Clarendon Press, 1990), pp. 75-8.

21 Michael Oakeshott, On History and other essays (Oxford: Blackwell, 1983), p. 38. 
settlement should re-establish the status quo that prevailed before the Thirty Years War.

The issue of sovereignty serves adequately to illustrate the difference between the emblematic and the historical characters of the Peace of Westphalia. The legal concept of sovereignty, however, although widely discussed among political theorists for more than a century before the Peace, was not central to the negotiations. Only in Spain's recognition of the United Provinces could sovereignty be read into the treatises. Instead the non-legal idea of autonomy dominated thinking in relation to the aspirations of states, both for the self-determination of the states within the German Empire, as well as for the well-established major states of Europe. The German principalities, for example, claimed their autonomy as a matter of ancient right.

To understand its historical identity, the Peace should not be viewed from present preconceptions about sovereignty. A more fruitful avenue is to see it in terms of the complex relations that pertained between the different political units in the Empire. During the later medieval period the Emperor was de jure sovereign, but some cities, such as Florence, were de facto sovereign. In addition, there were cities which were autonomous, having negotiated or had conferred upon them certain liberties. ${ }^{22}$ At the close of the later medieval period small urban elites came to the view that some political territories were relatively free from the authority relations that prevailed elsewhere, and more and more city-states in Northern Italy and Flanders claimed the right of self-determination in specific spheres of activity. ${ }^{23}$ In other words the relations among the multifarious communities remained complex and what was acknowledged in the Peace of Westphalia was their autonomy in certain spheres of action. ${ }^{24}$ Westphalia acknowledged the territorial autonomy of the states which comprised the Empire and conceded their right to make treatises with each other and with states outside the Empire on condition that such alliances were not directed against the Emperor or the Empire. The Peace essentially acknowledges the political and theoretical developments in the emergence of the modern state. The state had gradually come to claim a monopoly over declarations of war and peace, diplomatic representation and the making of treatises with foreign powers. ${ }^{25}$

What the Peace of Westphalia did in reality was to bring to the fore conceptual issues that the political philosopher was compelled to address. It is the contention of this article that many of the intimations which have later come to characterize the Westphalian model of states relations were conceptualized or captured in the writings of the most influential and widely read moral philosopher of the late seventeenth and eighteenth centuries, Samuel von Pufendorf. It was the varied nature of the political units that comprised post-Westphalian Europe that required analysis. His main theoretical preoccupation was not, unlike Grotius and Hobbes, the re-establishment of order out of chaos, but instead with the problem that

22 Joseph Canning, A History of Medieval Political Thought (London: Routledge, 1996), pp. 168-72; and Antony Black, Political Thought in Europe 1250-1450 (Cambridge: Cambridge University Press, 1992), p. 115.

23 Murphy, 'The Sovereign State System as Political-Territorial Ideal', in Biersteker and Weber (eds.), State Sovereignty as Social Construct, pp. 84-5.

24 Andreas Osiander, The States System of Europe, 1640-1990: Peacemaking and the Conditions of International Stability (Oxford: Clarendon Press, 1994), p. 78.

25 J. L. Holzgrefe, 'The Origins of Modern International Relations Theory', Review of International Studies, 15 (1989). 
Westphalia raised to pre-eminence: the character and status of the political units, and the different obligations of the person, both as a man and citizen, which for him necessarily entailed issues of sovereignty.

Pufendorf's immensely popular On the Duty of Man and Citizen (1673), whose title reflects its preoccupation, became a standard text-book in moral philosophy for nearly a century before Kant's Copernican revolution. ${ }^{26}$ Pufendorf's importance lies in the fact that he recognized that a gulf had opened up between traditional scholastic notions of natural law, and the naturalistic conception exemplified by Hobbes. He tried to reconcile justice and utility by acknowledging the role of selfinterest without abandoning the idea of obligation and duty under the natural law. Furthermore, Pufendorf's work reflects more systematically than any thinker up to his time the question of the collective rights of a community, and how they differ from those of an individual. Contrary to the thinking of most natural law thinkers, he gave greater priority to the rights of states. States, in his view, could regulate their size by restricting immigration, regulate trade, and ultimately held the supreme title to property in the realm. These aspects of his thought are most clearly expressed in relation to discussions arising from the discovery of the New World and the responsibilities of the European states under natural law and the law of nations to the non-European peoples. We should not lose sight of the fact, then, that the conceptual issues that Westphalia brought into focus were generated not only by the practices of states in continental Europe, but also by the issues raised by territorial expansion into the New World, which necessitated arriving at answers to complex questions about the rights and duties of states in relation to each other both in a European context, and in relation to their extra-European territories. Questions of the moral conditions of property ownership — what constitutes a valid claim, and what might be regarded as violations of the natural law and thus give rise to a just cause of war, entailing such questions as justifiable appropriation and reparationwere extensively discussed before Westphalia by such theorists as Vitoria and Grotius, and continued to resonate in the writings of such theorists and jurists as Locke, Pufendorf, Wolff and Vattel afterwards.

It is ironic that, in one of the few discussions available in English of Pufendorf's theory of state relations, his theoretical discussions of the constraints of natural law on the behaviour of states are dismissed as idealist, and it is suggested that his real contribution to understanding the behaviour of states is his formulation of the doctrine of raison d'état, to be found in his books on history. In his historical writings the universal ethical content of the natural law is almost totally eclipsed by the principles of state necessity and state interest. So much so that Meinecke praises Pufendorf as one of the great analysts of state interest and of reason of state, dismissing his theoretical work as too abstract, divorced from history, and marred by a reliance upon natural law that obstructs the emergence of genuine insights about the special character of individual state formations. ${ }^{27}$ Notwithstanding Meinecke's view, in so far as Pufendorf presented an elaborate theory of the post-Westphalian state system, he was, as one of his most recent editors has commented, 'the first

26 Peter Stein, 'From Pufendorf to Adam Smith: the Natural Law Tradition in Scotland', in Europäisches Rechtsolenken in Geschichte und Gegenwart (Munich: C. H. Beck, 1982), p. 667.

27 Freidrich Meinecke, Machiavellism: The Doctrine of Raison d'etat and its Place in Modern History (London: Routledge, 1962), p. 230. 
philosopher of modern politics' ${ }^{28}$ He was also the first person to hold a chair in natural law and the law of nations. For the century after his appointment at Heidelberg in 1660 almost every German university followed its example. His seminal tract, The Law of Nature and Nations, was the reference point for subsequent discussions of international relations by such eminent thinkers as Christian Wolff (1676-1756) and Emer Vattel (1714-1767).

\section{The state of nature}

Pufendorf's experience of the disintegration of the Holy Roman Empire, a disunited German Empire and the devastation consequent upon the Thirty Years War led him, like many of his contemporaries, to postulate a state of nature. The method of reasoning he used was the same as that of Hobbes, the hypothetical resolutive compositive method in which all extraneous secondary qualities are stripped away and man is revealed in his true state. Pufendorf does not subscribe to Hobbes's extreme individualism, nor is his state of nature characterized by a war of all against all. The principle of self-preservation does not absolve us of the obligations that the natural law impels us to perform towards other people (Natural State of Men, ch. 9). It is a social condition giving rise to congenital obligations to preserve and promote sociality. By the term sociable Pufendorf means 'an attitude of each man towards every other man, by which each is understood to be bound to the other by kindness, peace and love and therefore by a mutual obligation' (Law of Nature, II, iii, 15). From what we know of the human condition it follows that a fundamental law of nature must be to cultivate our sociableness which in turn promotes peace to the advantage of humanity. Self-preservation and the preservation of society, two principles that were later to constitute for Locke our duty to God, were for Pufendorf the fundamental laws of nature from which all others followed. ${ }^{29}$ For Grotius our social duties essentially amount to respecting each others' rights, and particularly not to infringe property rights. Sociality for Pufendorf entails more than the negative of desisting. This is an aspect of Pufendorf's theory that James Tully has misunderstood in suggesting that 'Sociableness, for Pufendorf, as for Grotius, is characterized essentially by the negative duty of respecting what belongs to others' ${ }^{30}$ In Pufendorf's view it is insufficient merely to desist from causing harm. In addition, Pufendorf maintains, we have a duty to promote and cultivate society. In fact he emphasizes sociality over self-interest in maintaining that the fundamental law of nature is, 'every man ought to do as much as he can to cultivate and preserve sociality', which means actively to promote it (Duty, I, 3, 8 and I, 7, 1). The obligation to do so is congenital rather than adventitious, and therefore, for Pufendorf, absolute (Duty, I, 6, 1).

28 James Tully, 'Introduction' to Samuel Pufendorf, On the Duty of Man and Citizen (Cambridge: Cambridge University Press, 1991).

29 Pufendorf, The Elements, OB. IV, 4. Pufendorf says: 'That each should be zealous so to preserve himself, that society among men be not disturbed'. He was later to give a much more active role to the individual for promoting society.

30 James Tully, A Discourse on Property: John Locke and his Adversaries (Cambridge: Cambridge University Press, 1980), p. 86. 
In addition we incur obligations and rights, such as those surrounding property, as a result of agreement. These are adventitious obligations. Obligations in the state of nature are imperfect because there is no supreme sovereign to enforce them, in other words they are not sanctioned by civil law. The fact that the obligations are imperfect make them no less morally obligatory than those perfect obligations enforceable in civil law.

While retaining Grotius's idea of natural sociality he wants to show that it is subverted by human imperfections. Pufendorf maintains that his investigation takes man as he finds him here and now 'tinged with depravity' (Natural State of Men, ch. 3). The original condition of man is brutish, but soon he realizes that mutual aid, the sharing of a common humanity, and being subject to the natural law, all impel him towards co-operation (Natural State of Men, ch. 6). An examination of the state of nature is supposed to impress upon the reader the need for civil society, even if this means enduring some of the imperfections of demanding and unreasonable rulers (Natural State of Men, ch. 23).

In opposition to Hobbes, Pufendorf argues that justice and injustice do not depend upon sovereigns, but are defined by natural law and bind the consciences of men (Law of Nature, VIII, i, 5). States, Pufendorf maintains, could never have been formed by compact had not some notion of justice and injustice existed prior to the institution of the state. What binding force could a pact have without the knowledge that it is just to keep it and unjust to break it?

Why is it necessary to sub-divide the world into states in preference to establishing a cosmopolitan global authority? Pufendorf's answer to this question reflects the political realities of the jealously guarded newly established principle of the autonomy of states, and the need to constrain their relations not only by a universal moral code, which he was well aware could not be adequately enforced in the absence of a common superior, but also by the justification of war as an instrument of compliance. Far from preventing war, the Westphalian settlement provided criteria for when it may legitimately be resorted to, and in this respect posited a rudimentary form of balance which was designed to prevent a preponderance of power being accumulated to the disadvantage of the rest of the states of Europe.

In Pufendorf's view, the human condition is precarious because of the uncertainties of the observance and enforcement of the precepts of natural law among a great multitude of people. Self-preservation is best achieved by conformity to the laws of nature, the enforcement of which becomes effective when backed by the power of the state. Security is the principal motivation for converting social communities into political states. ${ }^{31}$ States, although the creation of human will, are instituted by the command of God 'in so far as they serve as the means to the observance of natural law' (Law of Nature, VIII, iii, 2). What this implies is that we have an obligation to God to institute political society so that we may better fulfil our natures as social beings, protecting ourselves and actively protecting others. Consent obligates us to a specific form of government and sovereign. This is ultimately the position that Locke puts forward in the Second Treatise.

31 'the real and principal reason why the fathers of families left their natural liberty and undertook to establish states, was in order that they could surround themselves with defences against the evils which threaten man from his fellow man.' Law of Nature, VII, i, 7. 
Because of the 'huge dimensions' and diversity of mankind it is unrealistic to expect agreement on the details of a universal contract applicable to a multitude of different situations. Furthermore, the power of men is not so great that it could be exercised by one authority with equal force over all the world. The benefits gained from eliminating conflicts between states would be lost because of the clash of group interests within a world state (Law of Nature, VII, iii, 2: Elements, II, OB V, 1). ${ }^{32}$

In summary, our natural inclination towards peace is disturbed by the vast growth in population, exacerbated by defects in human nature which lead many to disregard the law of nature and render the condition uncertain and precarious for all. It is impractical to unite the whole of such a vast multitude into one state because the benefits gained by eliminating conflicts between nations would be lost by the diminution of the power of the state authority to contain internal disputes. A plurality of states, with contracts reflecting the diversity of mankind, is in Pufendorf's view, the most effective form of security. ${ }^{33}$ The social contract, for Pufendorf, institutes a political society in which the rights and duties of citizens are supplemented with the rights and duties of the sovereign. They are not the same rights and duties, but 'peculiar rights' and 'possessions' conferred upon the 'highest authority' in whose hands the care of the state has been placed (Law of Nature, VII, ii, 8-12: Duty, II, vi, 6-14).

\section{The State as a moral person}

At the time of the emergence of the modern state during the later medieval and early modern period, theorists found it difficult to characterize this relatively new entity in terms of the conceptual vocabulary available to them. In general the state was viewed in terms of concepts derived from Roman Law, either as a societas or a universitas. Both, however, were already heavily laden with connotations not entirely appropriate to an autonomous state. A societas entailed a contractual relationship between individuals, implying no corporate identity, and was the term used under private law to designate a partnership. It implied no identity beyond that of the individuals who comprised it. A societas was a partnership of individuals, each of whom was deemed capable of suing and of being sued independently of the whole which was itself devoid of corporate personality. A universitas, or corporation, on the other hand, had conferred upon it a legal or fictitious personality. In this capacity it could possess proprietary rights, but was not deemed to have a will, intentions, nor cognitive capacities. Furthermore a fictitious personality implied a higher legal authority to create it. ${ }^{34}$ It is one of Pufendorf's major strengths that when an available vocabulary inadequately captures what he sees to be the historical reality of his time he is quite prepared to extend or abandon it in favour of different terms of

32 Cf. Linklater, Men and Citizens, pp. 66-8.

33 For the uniqueness of Pufendorf's theory of social contract see Krieger, The Politics of Discretion, pp. $120-1$.

34 See Ernest Barker (ed.), The Social Contract (Oxford: Oxford University Press, 1961), Introduction; Otto Gierke, Natural Law and the Theory of Society 1500-1800, trans. and intro. Ernest Barker (Cambridge: Cambridge University Press, 1934); J. W. Gough, The Social Contract (Oxford: Clarendon Press, 1957), pp. 43-8; and Michael Oakeshott, On Human Conduct (Oxford: Clarendon Press, 1975), essay III. 
reference. Hobbes had argued that as a result of the social compact an artificial person is created, the embodiment of which was the person of the sovereign who in some way 'represented' the people, exercising his will on their behalf. The sovereign is the unity of the people. ${ }^{35}$ Pufendorf thought this depiction of the state a major theoretical advance, but thought that Hobbes did not go far enough. Pufendorf takes the further step of endowing the state with an individuality and personality distinct from the people who institute it, and the person of the ruler who exercises its authority. Moral entities are, for Pufendorf, individual persons or collections of persons united by a moral bond. The former he calls simple and the latter composite or compound 'moral persons' (Law of Nature, I, i, 12). A composite moral person is deemed to have one will, irrespective of the number of individuals who comprise it, and its actions are the actions of the whole body. Such entities may be endowed with rights and duties that none of the individuals comprising them could claim in their own right (Elements, I, DEF IV, 3). ${ }^{36}$ He maintains that:

in compound moral bodies something can be attributed to the body which cannot be attributed to all the members, that is, to them taken individually, or to any one of the individuals; and, therefore, the whole is an actual moral person distinct from the individual members, to which a special will, as well as actions and rights, can be attributed, which do not fall to the individuals (Law of Nature, VII, v, 5).

Furthermore, he argues that: 'The subjection and entwining of wills entailed in the social contract creates the state which is 'the most powerful of moral societies and persons'. ${ }^{37}$ Pufendorf is not here talking of a fictitious legal entity, but a real autonomous moral person with the capacity to will, deliberate and pursue purposes. The state has a personality and is the bearer of rights and duties. This 'actual' moral person has a will and personality independent of those who comprise it. Pufendorf was the first to apply the idea of the juristic moral person to the state and hence made it subject to the moral law of nature. It became a commonplace among writers on international relations to view the state as a moral person. His successors Wolff and Vattel, for example, extended the idea to designate states the moral subjects of the law of nations. ${ }^{38}$

\section{Sovereignty and sovereign powers}

The Peace of Westphalia inaugurated the widespread acceptance of the territorial state. ${ }^{39}$ In using the language of autonomy the Peace of Westphalia avoids having to enter into complex definitions of the different types of sovereignty which the various agreements might entail. The implications of what autonomy might entail, however, could not be avoided by political theorists. By 1576 Bodin had recognized the importance of the principle of sovereignty to understanding modern politics. His

35 T. Hobbes, Leviathan (Harmondsworth: Penguin, 1981), pp. 81 and 220.

36 Pufendorf, Law of Nature, I, i, 13: and On the Duty, II, 6, 10.

37 Pufendorf, Law of Nature, VII, ii, 5.

38 Peter Pavel Remec, The Position of the Individual in International Law According to Grotius and Vattel (The Hague: Martinus Nijhoff, 1960).

39 Knutsen, History of International Relations Theory, p. 71. 
theory further consolidated the trend towards establishing an abstract conception of the state distinguished from the person of the ruler. In this respect sovereignty is vested in the state and not in particular persons, and is undiminished by the passing of a regime or prince. Furthermore, sovereignty is absolute, subject to the constraints of natural law, the constitutional arrangements in which it is embedded, and the covenants entered into which are equally binding on all parties. ${ }^{40}$ Hobbes, writing in the immediate aftermath of the Thirty Years War and the Civil War in England, formulated an absolutist conception of sovereignty, equating justice and law with the will of the sovereign, aimed at minimizing the religious and political conflicts that had led to the collapse of civil society both on the continent and in Britain.

John Hoffman has been a severe critic of the idea of sovereignty, initially associating it inextricably with the state, but more recently he argues that the concept of sovereignty is historically evolving, and is such an embedded feature of the international landscape that it cannot be abandoned. It is so much part of the architecture of modernity that it should be redesigned and extended rather than abandoned. In order to overcome its inherent contradictions, however, it needs to be extended by severing the commonly assumed relation to the state. ${ }^{41}$ Pufendorf is certainly one of the theorists responsible for so firmly linking sovereignty with the state, but he was well aware that the absolutist conception of it did not fit well with the contingencies of historical reality. Unlike Hoffman, however, Pufendorf not only wants to extend the terms of reference of sovereignty, suggesting that absolute and limited conceptions of sovereignty are both species of the genus supreme sovereignty, he also believes that the traditional classification of states needs to be modified in such a way that the centrality of sovereignty is not obscured. Whereas Hoffman wants to deconstruct the state, Pufendorf wants to construct a firmer conception of it which bears the weight of the idea of supreme sovereignty.

In Pufendorf's view Hobbes fails adequately to acknowledge the distinction between supreme and absolute sovereignty choosing instead to equate the two (Law Of Nature, VII, vi, 13). Absolute sovereignty is a species of supreme sovereignty. Absolute sovereignty he defines as: 'the faculty of exercising every right on one's own judgement and choice' (Law of Nature, VII, vi, 10), or that the king 'has the final decision on his own judgement in matters which concern the commonwealth' (Law of Nature, VII, vi, 12). Certainly when reading his legalistic account of sovereignty in which he talks of its supremacy, indivisibility and exclusivity, with its holder being above the civil laws and accountable only to God, it appears that Pufendorf allows of no constitutional constraints upon the exercise of sovereign power (Law of Nature, VII, vi, 1-3). He nevertheless qualifies this initial impression by suggesting that it is not incompatible with the nature of sovereignty that it conform 'to a certain manner of procedure' (VII, vi, 7), in other words, that it may be procedurally limited.

Supreme sovereignty, for Pufendorf, merely denotes that there is no superior or equal authority in the state (Law of Nature, VII, vi, 10). Limited sovereignty, like

40 See Julian H. Franklin (ed.), On Sovereignty by Jean Bodin (Cambridge: Cambridge Universty Press, 1992), p. xxii.

41 John Hoffman, Beyond the State (Cambridge: Polity, 1995); and Sovereignty (Buckingham: Open University Press, 1998). 
Absolute, is a species of the genus and may be constrained by constitutional arrangements regarding conformity to 'certain basic laws' (Law of Nature, VII, vi, 10), ${ }^{42}$ or in accordance with specified procedures, such as consultation with a senate or council whose consent may be required (Law of Nature, VII, vi, 12). In equating limited sovereignty with procedural constraints Pufendorf believes that the supremacy of sovereignty is not undermined. The significance of his distinction between absolute and limited supreme sovereignty, as we will see, is of immense importance for his characterization of the principal actors in international relations.

Sovereignty is for Pufendorf the soul that animates the person of the state, but although instituted by human will, it is not its creation, nor dependent upon it. Sovereignty is consistent with nature in that it conforms with human sociality and right reason in better facilitating obedience to natural law. God sanctions sovereignty, but he does not confer it directly upon the rulers of states. He does so through the instrument of the human will. Pufendorf is at once undermining the doctrine of popular sovereignty without endorsing the divine right of kings (Law of Nature, VII, iii, 1-5). ${ }^{43}$ Human beings acting in time perform God's will by instituting arrangements suggested by right reason and consistent with the indubitable data of their nature. Insofar as sovereignty is both human and Divine, and in order to fulfil the purpose for which we associate and institute political society, it is in our interests to hold 'sacrosanct and inviolable' the civil sovereign. It is, Pufendorf argues, 'in the highest interest of mankind that the royal power be held sacred and free from the cavils of churlish men' (Law of Nature, VII, viii, 1 and VII, ii, 9 respectively). For Pufendorf the state is sacrosanct in retaining for itself special rights and duties that lesser moral persons do not have. The supreme sovereign entrusted with the safety of the people is ultimately responsible for all good and evil acts within the state (Law of Nature, VII, ix, 9).

\section{Types of State}

In placing such a high premium on sovereignty Pufendorf establishes the norm of what he calls regular or perfect states which conform to the standard types of democracy, aristocracy and monarchy. It is interesting that unlike philosophers from classical times up to his own time Pufendorf does not think it necessary to extend the traditional triadic categorization of states by re-labelling their corrupt forms because neither the nature nor legitimate object of power are altered (Law of Nature, VII, v, 11-14). ${ }^{44}$ Often the use of such terms as tyranny and oligarchy, he argues, are no more than an expression of dislike for the form of government. Pufendorf argues that sovereignty may be exercised well or badly, due either to a

42 It should be noted that Pufendorf's discussion is not entirely consistent. He begins by distinguishing between absolute and limited sovereignty, and then makes a distinction between absolute and supreme sovereignty as if they are quite distinct. The confusion is somewhat allayed if limited and absolute sovereignty are seen to be types of supreme sovereignty.

${ }^{43}$ For an excellent discussion of Pufendorf's doctrine of sovereignty see Dufour, 'Pufendorf', in J. H. Burns (ed.), Cambridge History of Political Thought, pp. 574-9.

${ }^{44}$ For an interesting discussion of these issues see Leonard Krieger, The Politics of Discretion: Pufendorf and the Acceptance of Natural Law (Chicago and London: University of Chicago Press, 1965), pp. 154-5. 
personal fault in the sovereign or sovereign body, or an institutional fault where the laws or offices of government are ill suited to the people or inadequate to perform the functions required of them (Duties, II, 8, 1-12). In this respect the corrupt forms exhibited no new or distinctive political principles which merited further categorization.

In contrast to the regular type he identifies the irregular or imperfect states. It is in this respect that he feels it necessary to extend the traditional Aristotelian categories because he believed them to be inadequate to conceptualize current political realities. The contrast between regular and irregular states rests upon the fact that only those of the former kind are 'directed by a single soul, as it were, or, in other words, that the supreme sovereignty, without division and opposition, is exercised by one will in all the parts of the state' (Law of Nature, VII, v, 2). Regularity, then, is judged by the criterion of unified power. ${ }^{45}$ In irregular states sovereignty is divided among its separate parts. It is clear that such an arrangement compromises the principle of supreme sovereignty. He disapproves of irregular states because they are inherently weak and unstable. In Pufendorf's view an irregular state is an 'ill-adjusted and sickly body' (Law of Nature, VII, iv, 14). The unity of such political entities does not lie in 'sovereignty which is the soul of the state', but instead depends by necessity on agreement among the separate parts. While not wishing to deny an irregular form the title of state, he maintains that it does not 'constitute a state properly so called but only a formless aggregate', an aberration that has departed from its pure form. ${ }^{46}$

Pufendorf's important contribution, however, is for the first time to characterize and provide a definition of a third type of international actor, such as the Swiss Confederation and the United Provinces, that conforms to neither of his distinctions, and this is essentially a system of states, of which confederations are a species. Confederations for Pufendorf are 'close' systems, in contrast to loose systems which are based upon much weaker bonds than shared monarchy or compact. All peoples are related through common origin and are subject to natural law; other states may have a bond because of a common racial origin, language or culture; and yet others may be closely tied as independent former colonies of a mother country. ${ }^{47}$ Pufendorf describes close political units as 'systems made up of several perfect states, which, in the eyes of those who are not versed in these matters, assume the false form of one state ...' (Law of Nature, VII, v, 7).

A system of states, strictly speaking, is a collection of regular states in which supreme sovereignty is limited, without compromising their integrity as regular states, by procedural agreements. It is here that his distinction between absolute and limited supreme sovereignty is of particular importance. A system of states is one where each has a special bond with the others, but nevertheless retains its own supreme sovereignty. The combined strength of such a system may be regarded as that of one state (Duties, II, 8, 13). There are two main species. First, several separate states may be united, most commonly by marriage or inheritance, in sharing the same monarch. This would be a personal union in the person of the

\footnotetext{
45 Alfred Dufour, 'Pufendorf', in J. H. Burns (ed.), The Cambridge History of Political Thought 1450-1700 (Cambridge: Cambridge University Press, 1988).

46 Cited by Krieger, The Politics of Discretion, 158, pp. 161-2.

47 See Murray Forsyth, Unions of States (Leicester: Leicester University Press, 1981), p. 74.
} 
monarch, but not necessarily a constitutional union. James VI of Scotland, for example, succeeded Elizabeth I to become James I of England. It is in identifying the second type that Pufendorf displays his particular insight. Here a system exists when several states bind themselves together by 'perpetual treaty', usually motivated by the desire to preserve their autonomy, but possessing insufficient power to protect themselves against enemies. In such cases it is usually agreed that some aspect of sovereignty is exercised with the consent of all, while all other aspects which are of little or no interest to the others, are exercised at the discretion of the individual states.

A treaty establishing such a system differs from simple treatises in that states permanently intertwine for purposes of the common object of security, rather than undertake to perform certain functions while retaining their complete autonomy. Permanent agreements among states give rise to adventitious obligations, created by mutual consent, and they are also imperfect because there is no supreme sovereign above the system of states to enforce them. They are, nevertheless, no less morally obligatory under the natural law than obligations attached to civil laws. Pufendorf expresses the difference between permanent and simple treaties by contrasting a typical clause from each type of agreement. He argues that: 'For there is a great deal of difference between "I will bring you aid in this war, and we shall consider in concert how we shall attack the enemy", and "No one of us who have entered this society will exercise his right of peace and war, save with the common consent of all" (Law of Nature, VII, v, 18). This is not to suggest that such systems of states cannot dissolve. Confederates may voluntarily leave when they begin to view their fellow confederates as a liability, or when internal wars are ignited. This is because each of the separate states in a system of states retains supreme sovereignty.

The German Empire constituted a problem for political theorists and commentators in that sovereignty proved difficult to locate. Pufendorf's theory served to provide the extended vocabulary in terms of which this evolving political unit could be discussed. Many theorists followed Bodin in acknowledging that it was a simple form of state, that is, a regular state in Pufendorf's terminology, and disputed whether it was a monarchy or aristocracy. Others broadly followed Althusius in viewing the German Empire as a mixed state, or an irregular state in Pufendorf's vocabulary. Pufendorf was critical of both characterizations. Using the pseudonym of Severus de Monzambano in order to avoid the charge of partisanship, he published in 1664 his The Constitution of the German Empire which traced the erosion of monarchical sovereignty and the emergence of an entity that came close to being a confederation.

Westphalia, in sanctioning war as a legitimate instrument for maintaining international agreements, for example in conceding the right of France and Sweden to intervene if the Emperor reneged on his renunciation of imperial ambitions, formalized the concept of a justifiable war. In recognizing the autonomy of most of the small states of central Europe, Westphalia rendered the Emperor politically impotent. The terms proscribed the Emperor making laws, raising taxes, recruiting soldiers, declaring war and making peace treaties without the consent of each state in the Empire. ${ }^{48}$ Furthermore, as Holzgrefe points out, in vesting the right of war in the sovereign, Pufendorf's denial of the right of war to subordinate magistrates also

${ }^{48}$ Forsyth, Unions of States, p. 80. 
reflects his dissatisfaction with the outcome of the Peace of Westphalia for the German Empire. The right to negotiate and enter upon treaties granted to the different German territories licensed alliances with foreign powers and undermined the unity of the whole. ${ }^{49} \mathrm{He}$ was critical of the Peace of Westphalia for diminishing the imperial power of the Emperor and weakening German unity by granting the former territorial princes formal autonomy.

Unlike Bodin, Pufendorf did not think that sovereignty resided in the Imperial Diet, nor did he think with Althusius that the Diet acted as a limitation on a monarchical form of state. The Diet more closely resembled the councils found in such confederations as the Swiss and the Dutch. The German Empire, he believed, had gradually evolved from a monarchical form, not into an aristocratic or democratic regular state, but into something more like an irregular state which bore some resemblance to a confederation or system of states. The result, when he initially tried to understand it, was something of a monstrosity, neither a sovereign state, nor a confederate system of states with a common interest: 'the very fact is that in the Empire, the head and the limbs stand opposed to each other like two hostile parties!' 50 To achieve harmony in the Empire is as difficult and laborious as tuning a harp, which despite the effort stays in tune for a short duration (Law of Nature, VII, v, 15). What prevented the Empire being a confederation was the somewhat anachronistic figure of the Emperor obstructing the constituent states from exercising supreme sovereignty in relation to each other and to the Imperial power. ${ }^{51} \mathrm{He}$ was concerned that the German Empire become a political force again. The process of degeneration from monarchy, in his view, was almost irreversible and the regularity of the state could not be restored without the risk of major catastrophe. ${ }^{52}$ In order to avoid further deterioration he recommends that regular states be established with well defined interests within a confederal system. If they found it necessary to appoint a leader, then the powers apportioned should be strictly limited by law and a representative council in order to avoid aspirations of sovereignty. ${ }^{53}$

\section{Conclusion}

The point to be emphasized is that even though states as moral persons inhabit a state of nature, in the same way that individuals are said to have done prior to the establishment of states, the laws of nature are equally as binding as those enforceable under civil law. Pufendorf posits a moral order that is universal, in which men owe duties to each other by the mere fact of being human and by being subject to God's sovereignty. ${ }^{54}$ Despite the fact that these duties are qualified by our obliga-

49 Krieger, The Politics of Discretion, pp. 162-3.

50 Knutsen, History of International Relations Theory, p. 71.

51 Holzgrefe, 'Origins of Modern International Relations Theory', p. 16.

52 Cited in Meinecke, Machiavellism, p. 229.

53 See Dufour, 'Pufendorf', p. 584.

54 'Now by our assertion that the maintenance of peace toward all men as such is a natural state of man, we mean that it has been instituted and sanctioned by nature herself without any human intervention, and that it rests therefore, upon that obligation of natural law, by which all men are bound, in so far as they are endowed with reason, and which does not owe its original introduction to any convention of men' (The Law of Nations, II, ii, 11). 
tions as citizens, Pufendorf's theory constitutes a rejection of the view that the moral order is confined to the internal relations of the state, and between which there can be no justice and injustice, or that any morality that may pertain between states is merely a matter of convention. He is sensitive to the historical emergence of the state and the complex relations which pertained among the very different actors in the Westphalian system. He recognized that both the categorization of states, and the conceptualization of sovereignty, had to be revised and extended to meet the prevailing historical contingencies. At the same time he tried to reconcile the duty of the state to protect its citizens with the universal claims of humanity. Conceiving the state as a person inevitably generated its own logic of explanation and justification of international conduct. Like the individual in the state of nature, but in reality more self-sufficient, the state should regard others of its kind as 'inconstant' friends who may presently become enemies. It should endeavour to live in peace, but also be mindful that the law of nature is often an inadequate constraint upon those who are no respecters of it.

His conclusions, especially those relating to sovereignty and the classification of states, should not be viewed as merely of historical interest. The Westphalian model in contemporary international relations theory is invariably characterized in terms of absolute sovereignty, which essentially means complete self-determination. The fact that for most states this is evidently not the case generates self-induced problems, even to the extent of suggesting that sovereignty might be an outmoded concept in the modern world. Sovereignty is a concept that has had to evolve to meet the needs of historical circumstances. The example of Pufendorf clearly demonstrates a point in time when the realities of the Westphalian system did not match the conceptual vocabulary in which to understand them. He extended this vocabulary both in terms of sovereignty and the classification of states, yet it is the more archaic meanings and concepts that he rejected which are still employed. His discussion of supreme sovereignty is certainly incomplete, and even somewhat evasive on crucial issues, but nevertheless, in conjunction with the idea of a system of states, we are better able to characterize such organizations as the European Union without getting embroiled in the debates about state power and autonomy generated when seen from the perspective of absolute sovereignty. Far from present day ambiguities in both the concepts of the state and sovereignty demanding their abandonment, the fact that they are deeply embedded in contemporary international relations, and are central to discussions regarding further integration among members of the European Union, requires that they are clarified and refined rather than abandoned. ${ }^{55}$ It is unlikely, for example, that a British government in the foreseeable future could persuade the electorate that sovereignty and statehood are no longer useful concepts when used in relation to the European Union. A far more useful strategy would be to retain their laudable evaluative connotations while extending their empirical references. To talk of divided sovereignty among the member states and the Union itself is politically divisive-sovereignty hived-off is sovereignty lost. But to argue that supreme sovereignty is completely compatible with permanent agreements to comply with

55 For arguments which recommend abandoning the idea of sovereignty, see Michael Newman, Democracy, Sovereignty and the European Union (London: Hurst, 1996), and Philip Lynch, 'Sovereignty and the European Union: Eroded, Enhanced, Fragmented', in Laura Brace and John Hoffman (eds.), Reclaiming Sovereignty (London: Cassell, 1996). 
procedural and legal processes which require mutual co-operation for mutual benefit is both politically and strategically more astute. It is the recognition that sovereignty can be limited by agreement, and that the idea of absolute sovereignty is therefore inapplicable, which makes collective decision-making compatible with supreme sovereignty. To describe the European Union as a system of states, in Pufendorf's sense, requires that each member retain the right to pull out, and therefore, as we saw, it is perfectly possible for systems of states to dissolve by voluntary withdrawal if the confederation is viewed as more of a hindrance than a help (Law of Nations, VII, v, 21).

Confederates may voluntarily leave when they begin to view their fellow confederates as a liability, or when internal wars are ignited. This is because each of the separate states in a system of states retains supreme sovereignty.

Let us take the cases of European citizenship and human rights, for example, to illustrate the extent to which discussion of European Union relations and human rights are understood and conceptualized in terms of sovereignty, the nation and statehood. Despite the fact that citizenship has taken on post-national dimensions in Europe, and that rights traditionally grounded in the state are articulated at the level of human rights, the sovereign nation state is still the reference point in which both are enjoyed. European Citizenship depends upon the prior enjoyment of national citizenship of a member state, and the enjoyment of human rights depends upon their recognition, implementation, and enforcement by sovereign states. As Soysal acknowledges, 'the sovereign nation state retains the formally and organisationally legitimate form venerated by the ideologies and conventions of transnational reference groups such as the UN, UNESCO, European Union and the like'. ${ }^{56}$

Notwithstanding Linklater's contention that a higher, more inclusive cosmopolitan citizenship is intimated in European citizenship, citizenship, nationality and the state are nevertheless currently inextricably linked. ${ }^{57}$ The Declaration on Nationality of a Member State, incorporated into the Treaty on European Union, unequivocally reaffirms the priority of national sovereignty over citizenship issues. It states: "the question whether an individual possesses the nationality of a member State shall be settled solely by reference to the national law of the member State concerned'. ${ }^{58}$ Nationality may be said to be the external aspect of citizenship. One's nationality determines to which state one belongs in the international context, and citizenship determines what rights one enjoys as a consequence of holding one's nationality. The rights that non-citizens enjoy are not rights of citizenship, but rights attached to a different status, which of course, vary according to the status one is afforded. Nationality relates to what Northedge described as external sovereignty. A state must be recognized for its nationals to have an international status. It is clear that in this respect citizenship of the European Union does not correlate with nationality of the Union, but with a member state. Does, then, the European Union have the external sovereignty which is necessary for statehood and the ascription of

56 Yasemin Nuhoglu Soysal, 'Changing Citizenship in Europe', in David Cesarani and Mary Fulbrook (eds.), Citizenship, Nationality and Migration in Europe (London: Routledge, 1996), pp. 24-5.

57 Andrew Linklater, The Transformation of Political Community (Cambridge: Polity Press, 1998), pp. 198-211.

58 Cited in Elspeth Guild, 'The Legal Framework of Citizenship of the European Union', in David Cesarani and Mary Fulbrook (eds.), Citizenship, Nationality and Migration in Europe (London: Routledge, 1996), p. 41. 
European nationality? One of the essential features of the emergence of the modern state has been the centralization of the power to make treatises and to be represented at international bodies and organizations. This entails the capacity to communicate with other governments in international law, fulfil international obligations, and to make decisions within its territory that may affect other states, or their nationals and companies. ${ }^{59}$ From the outset the European Union had the power conferred upon it to enter into bilateral or multilateral agreements with states or international organizations, and this power was more strictly defined in the Treaty on European Union (Maastrich). What is crucial, however, is that the power to act is constrained by the terms of reference that the member states have agreed upon, and its authority flows from the competencies conferred upon it in the context of the EC Treaty and the acts of accession. Elspeth Guild has argued that in terms of international law, the Community perceives itself to have an identity, and that the 'member states, which have ceded sovereignty to permit the Community to acquire such an identity, are under a duty not to undermine that identity so long as it is limited to the objectives of the treaty'. ${ }^{60}$ Such a view of the community is perfectly compatible with calling it a system of states in Pufendorf's sense of the term. The individual members are so closely linked that in many respects they appear to be one body, but nevertheless retain sovereign autonomy except in those respects in which they have agreed to act collectively. They are bound for these purposes by perpetual treaties which empower the union to act within the terms of reference specified. No sense of common identity, or common society is required above the basic cohesiveness of perceived common interest. Common interest is still very much the terms in which the Union is perceived by member states. The good of the whole, or the common good, is still very much subordinate to national interest, the terms in fact which characterize the debate within Britain about the merits of adopting the common currency. This is not to say that the Union cannot become more than it is, a system of states constituted by perpetual treatises which provide the framework for common action, and develop into a state with divided sovereignty dispersed throughout the Union. It would, then, in Pufendorf's terms, be an irregular state with all the problems that implied for him.

We are still a long way from superseding the Westphalian state system. Sovereignty, citizenship and nationality were all amorphous and ambiguous concepts from the beginning, gradually changing their character in conformity with circumstances, and the fact that they continue to be fluid does not necessarily signal the demise of the sovereign state. Ironically, Linklater's optimism for the transformation of sovereignty and citizenship becomes rather hollow when he cryptically specifies the conditions of such a transformation: 'The post-Westphalian era will begin when societies act as cosmopolitan citizens who aspire to make progress together towards the ethical ideal of a universal communication community'. ${ }^{61}$ Formal structures and legal frameworks do not a polity make! Democracy is premised on the existence of a demos, in the case of the European Union many peoples comprising one demos, as opposed to the current situation of many demoi, one European people. It is generally agreed that a collective civic identity is missing,

59 Guild, 'The Legal Framework of Citizenship of the European Union', p. 39.

${ }^{60}$ Ibid., p. 41.

61 Linklater, The Transformation of Political Community, p. 211. 
and that the European people do not perceive themselves as citizens in a wider moral community. This is the socio-psychological dimension which a focus upon structures and legal frameworks filters out. The differences on the issue of social cohesion within the EU are a matter of degree rather than of kind. ${ }^{62}$ Pooling the sovereignty of individual states does not dissolve sovereignty, it merely expands the community to which it is applicable. It is simply a relocation of the exclusionary discourse of the state on a greater scale. European Citizenship is designed to achieve a greater inclusivity within the Union, but it is nevertheless at the expense of a greater exclusivity in relation to outsiders because it requires member states to be more stringent in their immigration policies. Because of the harmonization of visa policies, for example, the UK is compelled to abandon its preferential treatment of some Commonwealth countries by requiring their citizens to obtain entry visas. Greater freedom of movement within the Union requires greater precision in defining who is to enjoy this privilege, and far from breaking down the strong correlation between citizenship and nationality, European citizenship is based on the prior claim to nationality in a member state. Although the European Commission was given extra powers under the Maastricht Treaty, its formal authority over matters of immigration is minimal. No member state has publicly expressed a willingness to cede it powers over immigration. There are vast differences in the requirements for acquiring citizenship throughout the European Union, to the extent that the issue has been described as the last bastion of sovereignty. In questions of citizenship the freedom of state action has been far less eroded than in other spheres of activity. ${ }^{63}$

Reconfiguring sovereignty, however, does not circumvent the inside/outside divide associated with statehood, because the question that is still uppermost in the mind of researchers is the extent to which the European Union has become a state by exhibiting those very characteristics of sovereignty traditionally associated with statehood. At a time when international relations theorists are highlighting the transformation of international politics with the dissolution of sovereignty by the advent and proliferation of non-governmental actors, one of the most prominent features of the New Europe is the extent to which Western European governments are developing new and more draconian measures of immigration control. ${ }^{64}$ Andrew Geddes has shown, for example, that immigration control and the admittance of asylum seekers at EU level have become much tougher. The freer movement of EU citizens within Europe precipitated firmer control of external borders. ${ }^{65}$

It has recently been observed that nation-building traditionally correlated the principles of nationality and rights within the very idea of citizenship, but of late the

62 See Dimitris N. Chryssochoou, 'Europe's Could-be Demos: Recasting the Debate', West European Politics, 19 (1996), pp. 787-801; Richard Münch, 'Between Nation-State, Regionalism and World Society: The European Integration Process', Journal of Common Market Studies, 34 (1996), pp. 379-402; and Rey Koslowski, 'Intra-EU Migration, Citizenship and Political Union', Journal of Common Market Studies, 32 (1994), pp. 369-402.

${ }^{63}$ R. Brubaker, Citizenship and Nationhood in France and Germany (Cambridge, MA: Harvard University Press, 1992), p. 179.

64 See Mark Mitchell and Dave Russell, 'Immigration, Citizenship and the Nation-State in the New Europe', in Brian Jenkins and Spyros A. Sofos (eds.), Nation and Identity in Contemporary Europe (London: Routledge).

65 Andrew Geddes, 'Immigrant and Ethnic Minorities and the EU's "Democratic Deficit", Journal of Common Market Studies, 33 (1995), pp. 197-217. 
rights that were regarded as embedded in a community have become more abstract and articulated at a general or universalistic level - the level of human rights - at the same time as difference and identity have become rooted in particularistic communities. ${ }^{66}$ This, of course, may be the case, but it ignores the pertinent point made by Pufendorf and which has become part of modern rights theory and practice, and that is rights, particularly those which are universal, such as those enshrined in the natural law, in order to become effective have to be both recognized and enforced, transforming them from imperfect rights whose enforcement is precarious, to perfect rights enforceable by law. The recent Pinochet case and the existence of ad hoc tribunals on war crimes and crimes against humanity testify to the importance of Pufendorf's view. The ruling of the British Law Lords in March 1999 against Augusto Pinochet is only one of many reminders of the fragile relation in which hundreds of millions of people worldwide stand to their governments, upon which they are dependent for the protection of their rights, but which nevertheless systematically violate them. In ruling that Pinochet is not immune from prosecution and can be extradited to Spain, the issue of where national sovereignty ends and where international law begins has come sharply into focus. Notwithstanding the collapse of the case on grounds of mental incapacity, the ruling acknowledges the authority of a Spanish court to indict Pinochet for human rights violations, including the torture and murder of his own citizens. The Law Lords ruled that Pinochet could not be tried for crimes committed before 1988, the year that Britain signed the UN Torture Convention incorporating such crimes into British law. ${ }^{67}$ The ruling in fact reaffirmed the primacy of sovereignty over international law and universal rights. In other words the existence of a right, a genuine claim, depends upon recognition and enforcement by sovereign states, and in this respect they are similar to civil laws. Such a view is confirmed by the Commission of Human Rights in consistently disavowing competence to consider the business of, or decisions made by, the Community's institutions, because it is not a signatory to the Convention on Human Rights.

66 Soysal, 'Changing Citizenship in Europe', p. 18.

67 Britain's statutory extradition law operates on the principle of 'double criminality' which prevented the Law Lords from being able to extradite Pinochet for crimes committed before 1988, the year that extra-territorial torture became an offence in British law. Geoffrey Robertson, Crimes Against Humanity: The Struggle for Global Justice (Harmondsworth: Penguin, 2000), p. 373. 
